\title{
Diversity and ecological features of symbiotic communities associated with large hermit crabs along the southern part of the Russian coast of the Sea of Japan
}

\author{
Разнообразие и экологические особенности симбиотических \\ сообществ, ассоџиированных с раками-отшельниками вдоль \\ южной части российского побережья Японского моря
}

\author{
Ivan N. Marin ${ }^{1}$, Sergey Yu. Sinelnikov ${ }^{1,2}$ \\ И.Н. Марин ${ }^{1}$, С.Ю. Синельников ${ }^{1,2}$
}

\footnotetext{
${ }^{1}$ A.N. Severtzov Institute of Ecology and Evolution of RAS, Leninsky prosp. 33, Moscow, 117071, Russia. E-mail: coralliodecapoda@mail.ru (corresponding author)

${ }^{1}$ Институт проблем экологии и эволюции им. А.Н. Северцова РАН, Ленинский просп., 33, Москва, 119071, Россия.

2 I.D.Papanin Institute for biology of inland waters of RAS, Borok, Nekouzsky region, Yaroslavl oblast, 152742 Russia. E-mail: sinelnikoff@yandex.ru

${ }^{2}$ Институт биологии внутренних вод им. И.Д. Папанина РАН, п. Борок, Некоузский р-н, Ярославская обл., 152742 Россия.
}

KEY WORDS: Symbiosis, communities, associations, Decapoda, Paguroidea, Amphipoda, Polychaeta, hermit crab, ecological niche, competition, localization, the Sea of Japan.

КЛЮЧЕВЫЕ СЛОВА: Симбиоз, сообщества, ассоциации, Decapoda, Paguroidea, Amphipoda, Polychaeta, раки-отшельники, экологические ниши, конкуренция, локализация, Японское море.

ABSTRACT. The paper presents a preliminary description of several most typical symbiotic communities formed in association with large subtidal hermit crabs in the Russian waters of the Sea of Japan. The annotated list of macrosymbionts found on hermit-crabs is presented. Localization on the host and possible competitive relationships with other symbionts are described for the number of model species of macrosymbionts.

РЕЗЮМЕ. В работе приведены предварительные данные исследования симбиотических сообществ, ассоциированных с крупными сублиторальными раками-отшельниками в российских водах Японского моря. Описано нескольких типов наиболее характерных симбиотических сообществ. Представлен аннотированный список видов макросимбионтов, обнаруженных на раках-отшельниках. Для ряда модельных видов макросимбионтов отдельно рассмотрена локализация на хозяине и возможные конкурентные взаимоотношения с другими симбионтами.

\section{Introduction}

Representatives of the superfamily Paguroidea (Crustacea: Decapoda: Anomura), or hermit crabs, are a group of decapod crustaceans with soft asymmetrical abdomen usually hidden in shells of gastropod mollusks (gastropods), sponges or wreck of a sunken tree. This group of crustaceans is very diverse and wide- spread in the World Ocean from the Arctic to the Antarctic, from the coastline to bathyal depths with more than 1500 species of hermit crabs have been currently described; there is even one family of hermit crabs, Coenobitidae, living on the land [Markham, 2010; McLaughlin et al., 2010]. Using foreign objects to protect their body and constantly moving along the seabed, hermit crabs unwittingly create an ideal environment for other marine animals populating their "house" both inside and outside of the shell. Such groups of associated species form symbiotic communities often including more than 10-20 species on the same host. There are more than 2000 known symbiotic species of marine invertebrates permanently or temporarily associated with hermit crabs [Williams, 1995; Williams, McDermott, 2004; Markham, 2010; McDermott et al., 2010].

Among the symbionts of hermit crabs nearly all major taxa of marine animals have been observed from microscopic protozoa to large polychaetes whose length can exceed the length of the host [McDermott, 2001; Williams, McDermott, 2004; McDermott et al, 2010]. The most diverse group associated with hermit crabs are crustaceans (Arthropoda: Crustacea), including small amphipods (Amphipoda). Amphipods are often involved into a symbiotic relationship with hermit crabs and related lithodids (king crabs) combined into the superfamily Paguruoidea [Reiss et al., 2003; Williams, McDermott, 2004; Butler, Butler, 2012, 2013]. Currently 6 families of Amphipoda, Amphilochidae [Myers, 1974], Liljeborgiidae [Taylor, 1979; Cuadras, 
Pereira, 1977], Stenothoidae [McGrath, 1978; Marin, Sinelnikov, 2012], Photidae [Reiss et al., 2003], Ischyroceridae [Williams, McDermott, 2004; Dvoretsky, Britayev, 2009] and Pleustidae [Marin et al., 2013], involving into a symbiotic relationships with hermit crabs, are discovered among more than 100 known amphipod families. However, in our view, this list is by far to be complete, since hermit crabs symbionts are often lost during the collection. Environmental aspects of the relationship of symbiotic amphipods and their hosts also often remain unstudied. Nevertheless, the role of symbiotic community is very important and often even plays a key role during the life of the host [Glynn, 1983a, b, 1987; Glynn, Krupp, 1986; Stimpson, 1990].

About 40 species of hermit crabs from 3 families, Paguridae, Diogenidae, and Parapaguridae, are presently included in the list of the Russian fauna; most of species are known from the Far-Eastern seas of Russia [Makarov, 1938; Vinogradov, 1950; Marin et al., 2011, 2012; Marin, 2013; Marin, Kornienko, 2014]. The greatest diversity of hermit crabs among the seas of Russia are recorded in the Sea of Japan (over 30 species), which is generally characterized by the most rich fauna among Russian seas [Anosov et al., 2014]. Being relatively large mobile organisms, hermit crabs create a favorable environment for the formation of symbiotic communities in the Sea of Japan [Williams, McDermott, 2004]. In 2012, inside shells and sponges occupied by hermit crabs Pagurus pectinatus (Stimpson, 1858), $P$. parvispina Komai, 1997 and Elassochirus cavimanus (Miers, 1879) (Paguridae) in the Sea of Japan, a new species of symbiotic amphipod Metopelloides paguri Marin et Sinelnikov, 2012 (Crustacea: Amphipoda: Stenothoidae) was discovered [Marin, Sinelnikov, 2012]. This finding became the second discovery of symbiotic amphipods living inside the shell of hermit crabs in the fauna of Russia [Gurjanova, 1938; Marin, Sinelnikov, 2012]. Later, during an integrated investigation of hermit crab associates in Vostok Bay of the Sea of Japan, two symbiotic species of amphipods, Sympleustes japonicus (Gurjanova, 1938) (Pleustidae) and Ischyrocerus commensalis Chevreux, 1900 (Ischyroceridae) [Marin et al., 2013] as well as polychaete Cheilonereis cyclurus (Harrington, 1897) (Polychaeta: Errantia: Nereididae) living inside the shell occupied by hermit crabs, and parasitic isopod Pseudione giardi Caiman, 1898 (Crustacea: Isopoda: Bopyridae) attaching to the abdomen of hermit crabs, were also recorded [Marin, unpublished]. One of amphipod species, I. commensalis, is also known as a symbiont of Far-Eastern lithodid crabs (Crustacea: Decapoda: Lithodidae) related to hermit crabs and for a newly introduced king crab (Paralithodes camtschaticus (Tilesius, 1815) (Lithodidae)) population in the Barents Sea [Gurjanova, 1951; Dvoretsky, Britayev, 2009; Butler, Butler, 2012; Dvoretsky, Dvoretsky, 2013]. Unfortunately, details of relationships with the host are still unknown for the majority of hermit crab associated symbionts.

This paper presents data on the species composition of macrosymbionts of large and common species of hermit crabs in the Russian coastal zone of the Sea of Japan, their localization on the host and possible competitive interactions between different symbiotic species. Ecological feature, localization and occurrence in different types of symbiotic communities of 5 species of macrosymbionts, namely amphipods $M$. paguri, $S$. japonicus, $I$. commenalis, bopyrid isopods $P$. giard $i$ and polychaetes C. cyclurus, are presented. Also in this paper we argue that associated symbiotic community is very important to the life of hermit crabs.

\section{Materials and methods}

The study of hermit crabs was conducted in the offshore area in South Primorye (north-western coast of the Japanese sea from Cape Povorotnyi $\left(42^{\circ} 40^{\prime} 38^{\prime \prime} \mathrm{N}\right.$ $\left.133^{\circ} 02^{\prime} 33^{\prime \prime} \mathrm{E}\right)$ to the southern border of Posjeta Bay, the Tumannaya River (Tumangan) (42。17'37"N $130^{\circ} 42^{\prime} 02^{\prime \prime E}$ ), mainly in the Vostok and Posjeta Bays of the Sea of Japan in summer season of 2012-2014 years. To explore the regional diversity of hermit crabs we used all possible types of sampling from the littoral zone to sublittoral trawling (deep to $220 \mathrm{~m}$ ). Collections of Institute of Marine Biology (IMB FEB RAS, Vladivostok), Zoological Institute of RAS (ZIN RAS, St. Petersburg), Zoological Museum of Moscow State University (Moscow) and personal author's collections from the region were processed for additional material on hermit crab associates. During field sampling symbiotic animals were washed from several large species of hermit crabs such as Pagurus ochotensis Brandt, 1851 (Fig 1b), Pagurus middendorffii Brandt, 1851 (Fig. 5h), P. pectinatus (Stimpson, 1858) (Fig. 1b-d), P. brachiomastus (Thallwitz, 1892), P. parvispina Komai, 1997 (Fig. 1e), P. gracilipes (Stimpson, 1858) (Fig. 5b), and Discorsopagurus maclaughlinae Komai, 1995 (Paguridae) (Fig. 5e) most common in subtidal waters of the Sea of Japan. Washouts were conducted through the fine gauze using $5 \%$ solution of ethyl alcohol (ethanol) and a weak solution of clove oil. For complete studying of associated fauna washouts from 38 individuals of $P$. ochotensis, 22 individuals of $P$. pectinatus and 10 individuals of $P$. brachiomastus collected with the help of SCUBA in shallow waters $(5-30 \mathrm{~m})$ of Vostok Bay and Furuhelma Island, and 35 individuals of $P$. pectinatus and 18 specimens of $P$. parvispina collected by fishing trawls at depths of $40-80 \mathrm{~m}$ in the Vostok Bay were examined. Shallow water hermit crabs were collected underwater in individual plastic bags to prevent loss of the symbionts, and then examined in the laboratory as described above. In parallel underwater observation of symbionts localizations was conducted accompanied with underwater photographing in situ. During the extraction process localization of all symbionts was also noted. Photos of amphipods and other symbionts were made in the laboratory using the camera attached to Olympus stereo microscope. 


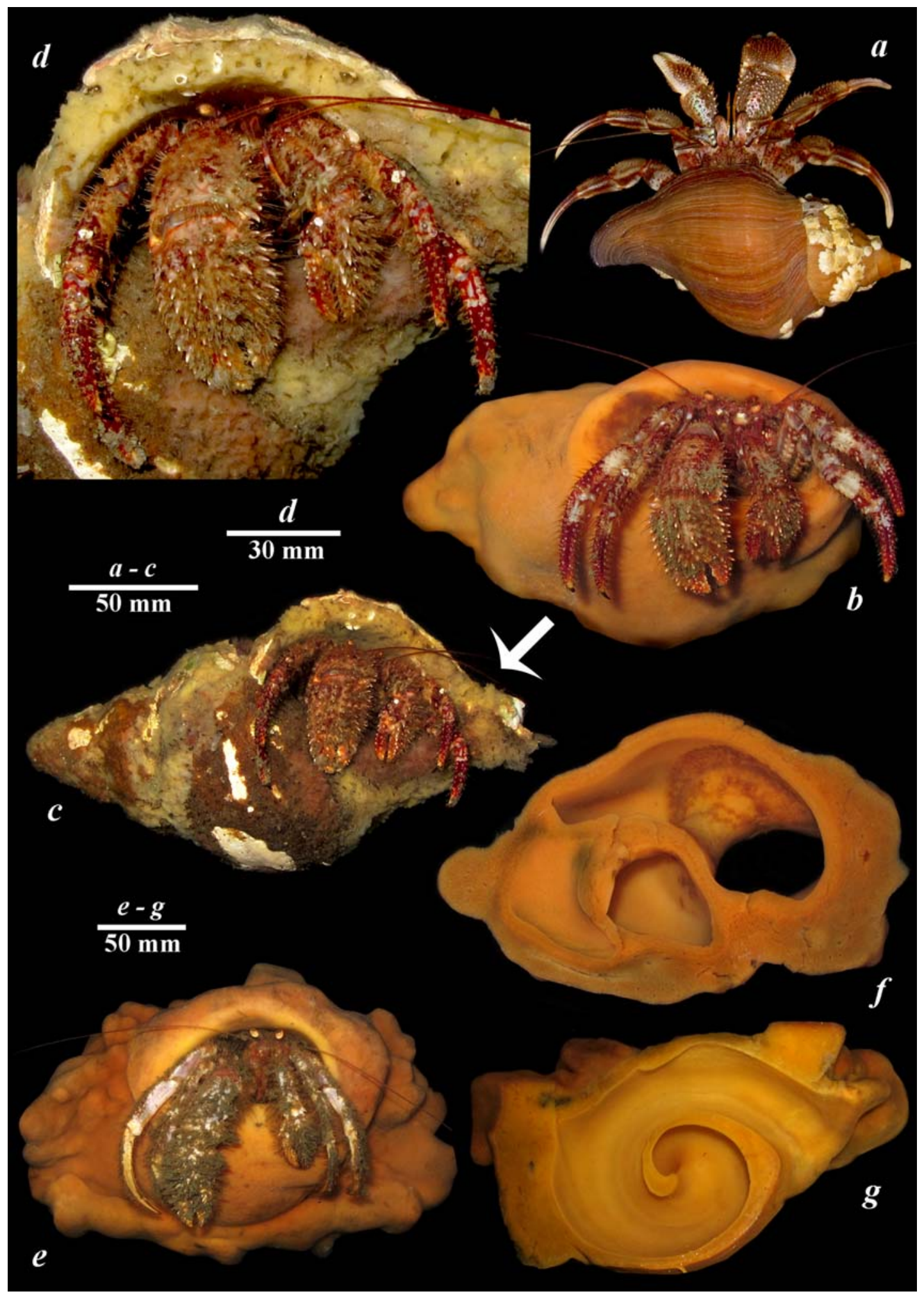

Fig. 1. a-Pagurus ochotensis Brandt, 1851 in the shell of gastropod Neptunea sp., Vostok Bay, depth $5 \mathrm{~m} ; b-$ Pagurus pectinatus (Stimpson, 1858) in sponge Suberites sp., Vostok Bay, depth 40-50 m; $c$ - the same shell purified from the sponge; $d$ - the same shell, the mouth of shell, partially dissolved by sponge; $e-$ Pagurus parvispina Komai, 1997 in sponge Suberites sp., depth 50-80 m; $f$, $g-$ canal inside sponge Suberites sp. occupied by hermit crab.

Рис. 1. a - Pagurus ochotensis Brandt, 1851 в раковине гастроподы Neptunea sp., зал. Восток, 5 м; $b$ - Pagurus pectinatus (Stimpson, 1858) в губке Suberites sp., зал. Восток, 40-50 м; $c$ - тот же экземпляр с очищенной от губки раковиной; $d-$ тот же экземпляр, устье раковины, разъеденное губкой; $e$ - Pagurus parvispina Komai, 1997 в губке Suberites sp. 50-80 м; f, $g$ - канал, в котором обитает раки-отшельники, внутри губки Suberites sp. 
Table 1. Macrosymbionts observed in associations with hermit crabs in the Sea of Japan. The underlined species were se-

lected as models for further ecological researches.

Таблица 1. Макросимбионты, обнаруженные в ассоциациях с раками-отшельниками в Японском море. Подчеркнуты те виды, для которых представлены исследования по экологии.

\begin{tabular}{|c|c|c|}
\hline Species of symbiont & Taxonomy & $\begin{array}{l}\text { Host and localization } \\
\end{array}$ \\
\hline $\begin{array}{l}\text { Suberites domuncula (Olivi, 1792) } \\
\text { (Fig. } 1 b, e-g \text { ) }\end{array}$ & $\begin{array}{l}\text { Porifera: Demospongiae: } \\
\text { Suberitidae }\end{array}$ & $\begin{array}{l}\text { Settling on the surface of the shell, occupied by hermit } \\
\text { crab, and later, after dissolution of the shell, repeating } \\
\text { the inner shape of the shell became the main substrate for } \\
\text { hermit crab occupation. Usually occupied by } P \text {. } \\
\text { pectinatus } P \text {. parvispina and } P \text {. brachiomastus, rarely by } \\
P \text {. ochotensis. }\end{array}$ \\
\hline $\begin{array}{l}\text { Unidentified turbellarian (possibly, } \\
\text { representative of the genus } \\
\text { Stylochus Ehrenberg, 1831)) }\end{array}$ & $\begin{array}{l}\text { Platyhelminthes: } \\
\text { Polycladida }\end{array}$ & $\begin{array}{l}\text { Lives inside the shell occupied by hermit crabs, usually, } \\
\text { in the recent turnover at the base of the columella. It } \\
\text { occurs in almost all shells occupied by large specimens } \\
\text { of } P \text {. ochotensis, P. pectinatus and } P \text {. brachiomastus }\end{array}$ \\
\hline $\begin{array}{l}\text { Colonial hydroids (Hydractinia } \\
\text { echinata (Fleming, } 1828 \text { ) or } \\
\text { Schuchertinia milleri (Torrey, } \\
\text { 1902)) (Figs. } 4 a, g, 5 \text { ) }\end{array}$ & $\begin{array}{l}\text { Cnidaria: Hydrozoa: } \\
\text { Hydractiniidae }\end{array}$ & $\begin{array}{l}\text { Settling on the surface of the shell, occupied by hermit } \\
\text { crab, and later, after dissolution of the shell, repeating } \\
\text { the inner shape of the shell became the main substrate for } \\
\text { hermit crab occupation. Observed in associations with } P \text {. } \\
\text { middendorffii, P. ochotensis and Labidochirus anomalus } \\
\text { (Balss, 1913) }\end{array}$ \\
\hline Gastropods Crepidula $s p$ & $\begin{array}{l}\text { Mollusca: Gastropoda: } \\
\text { Calyptraeidae }\end{array}$ & $\begin{array}{l}\text { Lives inside on the inner surface of shells occupied by } \\
\text { hermit crabs, usually close to the shell mouth. Occurs in } \\
\text { almost all shells occupied by large specimens of } P \text {. } \\
\text { ochotensis, } P \text {. pectinatus and } P \text {. brachiomastus }\end{array}$ \\
\hline $\begin{array}{l}\text { Dipolydora commensalis } \\
\text { (Andrews, 1891) (Fig. } 4 h \text { ) }\end{array}$ & $\begin{array}{l}\text { Polychaeta: Sedentaria: } \\
\text { Spionidae }\end{array}$ & $\begin{array}{l}\text { On the surface of shells occupied by hermit crabs } \\
\text { inhabiting a wide range of hosts (Williams, McDermott, } \\
\text { 1997; Dualan, Williams, 2011) }\end{array}$ \\
\hline $\begin{array}{l}\text { Different polychaetes-spirorbids } \\
\text { including Bushiella sp. and Circeis } \\
\text { armoricana Saint-Joseph, } 1894 \\
\text { (Fig. } 4 k \text { ) }\end{array}$ & $\begin{array}{l}\text { Polychaeta: Sedentaria: } \\
\text { Spirorbidae }\end{array}$ & $\begin{array}{l}\text { On the surface of shells occupied by different hermit } \\
\text { crabs and carapace of hermit crab } P \text {. ochotensis }\end{array}$ \\
\hline $\begin{array}{l}\text { Cheilonereis cyclurus (Harrington, } \\
\underline{1897)} \text { (Fig. 4i) }\end{array}$ & $\begin{array}{l}\text { Polychaeta: Errantia: } \\
\text { Nereididae }\end{array}$ & $\begin{array}{l}\text { Lives inside the shell occupied by the hermit crabs in the } \\
\text { last turnover of the shell behind the body of the host } \\
\text { crab. Probably feeds on the faeces of the host. Found in } \\
\text { shells occupied by large specimens of } P \text {. ochotensis, } P \text {. } \\
\text { pectinatus and P. brachiomastus }\end{array}$ \\
\hline $\begin{array}{l}\text { Peltogaster boschmai Reinhard, } \\
1944 \text { (Fig. } 5 f, g \text { ) }\end{array}$ & $\begin{array}{l}\text { Crustacea: Cirripedia: } \\
\text { Rhizocephala: } \\
\text { Peltogastridae }\end{array}$ & $\begin{array}{l}\text { Single individuals of parasite were found attached to the } \\
\text { abdomen of Discorsopagurus maclaughlinae Komai, } \\
1995\end{array}$ \\
\hline $\begin{array}{l}\text { Peltogasterella gracilis (Boschma, } \\
\text { 1927) (Fig. } 5 a, b \text { ) }\end{array}$ & $\begin{array}{l}\text { Crustacea: Cirripedia: } \\
\text { Rhizocephala: } \\
\text { Peltogastridae }\end{array}$ & $\begin{array}{l}\text { Clumps of parasites (colonial form) were found attached } \\
\text { to the abdomen of } P \text {. ochotensis, P. pectinatus, Pagurus } \\
\text { gracilipes (Stimpson, 1858) }\end{array}$ \\
\hline Barnacles Balanus spp. (Fig. $4 g$ ) & $\begin{array}{l}\text { Crustacea: Cirripedia: } \\
\text { Balanidae }\end{array}$ & $\begin{array}{l}\text { Numerous representatives of the genus Balanus Costa, } \\
1778 \text { were found on the surface of shells of almost all } \\
\text { species of hermit crabs found in the region. The current } \\
\text { species were not identified as we suggest them as non- } \\
\text { specific settling animals, covered any solid substrate }\end{array}$ \\
\hline $\begin{array}{l}\text { Pseudione giardi Caiman, } 1898 \\
\text { (Fig. } 4 b, e)\end{array}$ & $\begin{array}{l}\text { Crustacea: Isopoda: } \\
\text { Bopyridae }\end{array}$ & Attached to the abdomen of $P$. ochotensis \\
\hline $\begin{array}{l}\text { Sympleustes japonicus (Gurjanova, } \\
\text { 1938) (Fig. 3e) }\end{array}$ & $\begin{array}{l}\text { Crustacea: Amphipoda: } \\
\text { Pleustidae }\end{array}$ & $\begin{array}{l}\text { Lives on the surface (inner of outer) close to the mouth } \\
\text { of the shell or sponge occupied by hermit crabs, } \\
\text { juveniles of amphipods were found inside osculum of } \\
\text { sponge. For host specificity see Tables } 2,3\end{array}$ \\
\hline $\begin{array}{l}\text { Ischyrocerus commensalis } \\
\text { Chevreux, } 1900 \text { (Fig. } 3 b)\end{array}$ & $\begin{array}{l}\text { Crustacea: Amphipoda: } \\
\text { Ischyroceridae }\end{array}$ & $\begin{array}{l}\text { Usually adult and juveniles specimens of the species } \\
\text { were found on appendages of host. For host specificity } \\
\text { see Tables } 2,3\end{array}$ \\
\hline $\begin{array}{l}\text { Metopelloides paguri Marin \& } \\
\underline{\text { Sinelnikov, 2012 (Fig. } 3 g)}\end{array}$ & $\begin{array}{l}\text { Crustacea: Amphipoda: } \\
\text { Stenothoidae }\end{array}$ & $\begin{array}{l}\text { Lives inside the shell occupied by hermit crab, usually in } \\
\text { the cavity behind the body of the host. Probably feeds on } \\
\text { the faeces of the host. For host specificity see Tables } 2,3\end{array}$ \\
\hline
\end{tabular}


Table 2. The occurrence of model species macrosymbionts in different communities associated with hermit crabs. Таблица 2. Присутствие модельных видов макросимбионтов в различных сообществах, ассоциированных с ракамиотшельниками.

\begin{tabular}{|c|c|c|c|c|c|}
\hline \multirow{2}{*}{ Host species } & \multicolumn{5}{|c|}{ The species of macrosymbiont } \\
\hline & M. paguri & S. japonicus & I. commensalis & P. giardi & C. cyclurus \\
\hline \multicolumn{6}{|c|}{ Gastropod shell } \\
\hline P. ochotensis $(0-5 \mathrm{~m})$ & - & + & - & + & + \\
\hline $\begin{array}{l}\text { E. cavimanus }(40-60 \mathrm{~m}) \\
\text { (collections) }\end{array}$ & + & + & + & - & - \\
\hline P. parvispina $(40-60 \mathrm{~m})$ & + & + & + & - & - \\
\hline P. pectinatus $(40-60 \mathrm{~m})$ & + & + & + & - & - \\
\hline P. brachiomastus $(5-30 \mathrm{~m})$ & - & + & - & + & + \\
\hline \multicolumn{6}{|c|}{ Sponge Suberites } \\
\hline P. pectinatus $(40-60 \mathrm{~m})$ & + & + & + & - & - \\
\hline P. parvispina $(40-60 \mathrm{~m})$ & + & + & + & - & - \\
\hline \multicolumn{6}{|c|}{ Hydractinia } \\
\hline P. ochotensis $(5-30 \mathrm{~m})$ & - & + & - & + & + \\
\hline
\end{tabular}

\section{Results}

Diversity of macrosymbionts associated with hermit crabs

On the surface and inside the shells occupied by hermit crab as well as on the body of hermit crabs we found and identified 14 species of large marine invertebrates (Table 1). Most of collected animals are specific symbionts of hermit crabs in general possessing low level of the specialization to particular host species.

Five model species of macrosymbionts were selected for ecological study, including 3 species of amphipods (M. paguri, S. japonicus, I. commensalis), polychaete $C$. cyclurus and parasitic bopyrid isopod $P$. giardia) (Table 1).

Types of communities of macrosymbionts found on hermit crabs

Three different symbiotic communities formed on the basis of the substrate forming "house" occupied by hermit crab were observed: (1) gastropod shells (Fig. $1 a)$; (2) sponges of the genus Suberites Nardo, 1833 (identified as Suberites domuncula (Olivi, 1792) (Porifera: Demospongiae: Suberitidae) (Fig. 1b,e)); and (3) colonies (cenosarc) of Hydractinia (Cnidaria: Hydrozoa: Hydractiniidae) (Hydractinia echinata (Fleming, 1828) or Schuchertinia milleri (Torrey, 1902), both hydractinians species are known as symbionts of hermit crabs in the Arctic and North Pacific Ocean) (Figs. 4a, 5h).

1) Gastropod shells were populated by almost all species of collected hermit crabs; only D. maclaughlinae usually lives inside tubes of serpulid polychaetes [see Marin et al., 2012]. In association with hermit crabs living in gastropod shells all macrosymbionts were noted (Table 1). At the same time, the shell is usually populated by specific ectosymbionts like sponges Suberites and hydroids Hydractinia which eventually overgrow it (Figs. 1b, 4a) and lately completely dissolve (replace) the shell (Fig. 1c, d). Nevertheless, the inner channel of sponges or hydractinian cenosarc replacing the shell completely resembles a helix of gastropod shell (Fig. 1f, g) allowing hermit crab to continue living inside comfortably. In any case, juveniles of hermit crabs primary occupy only gastropod shells.

2) Sponge Suberites are usually inhabited by large specimens of hermit crabs $P$. ochotensis, $P$. pectinatus and $P$. parvispina (Figs. $1 b, e, 2 a, h, i)$. Most frequently hermit crab inhabiting sponges were found at the depths greater than $30 \mathrm{~m}$, which primarily can be explained by the rapid leaching of calcium from the gastropod shells at such depths, its dissolution and easily replacement of the shell with a sponge tissue. At lower depths, apparently, hermit crabs prefer living in gastropod shells and replace them during the lifetime. At the depths greater than $70 \mathrm{~m}$, hermit crabs were found only in sponges, which we attribute to a very rapid dissolution of shells at this depth, as well as fewer opportunities hermit crab to find suitable shells. At the same time, juveniles and small specimens hermit crabs were never observed inside sponges. Some of macrosymbionts such as bopyrid $P$. giardi and polychaetes $C$. cyclurus (Tab. 2) were never observed within symbiotic communities associated with hermit crabs living inside sponges, possibly, because of sponge toxicity.

3) Cenosarc of Hydractinia. Usually Pagurus ochotensis (Fig. 4a), P. middendorffii (Fig. 5h) and Labidochirus anomalus (Balss, 1913) living in shallow waters not deeper than 25-30 m we found occupying hydractinian cenosarcs. Hydractinian larvae similar to sponges (see above) first settle on the surface of the gastropod shell occupied by hermit crab and eventually overgrown it completely. Further, under the action of the active substances secreted by hydroid the shell is dissolved completely and hermit crab remains in cenosarc which has an internal cavity follows the helix of the shell. It is known that the association of Hydractinia and hermit crabs has a mutualistic character as $\mathrm{Hy}$ dractinia gets mobility while hermit became protected 


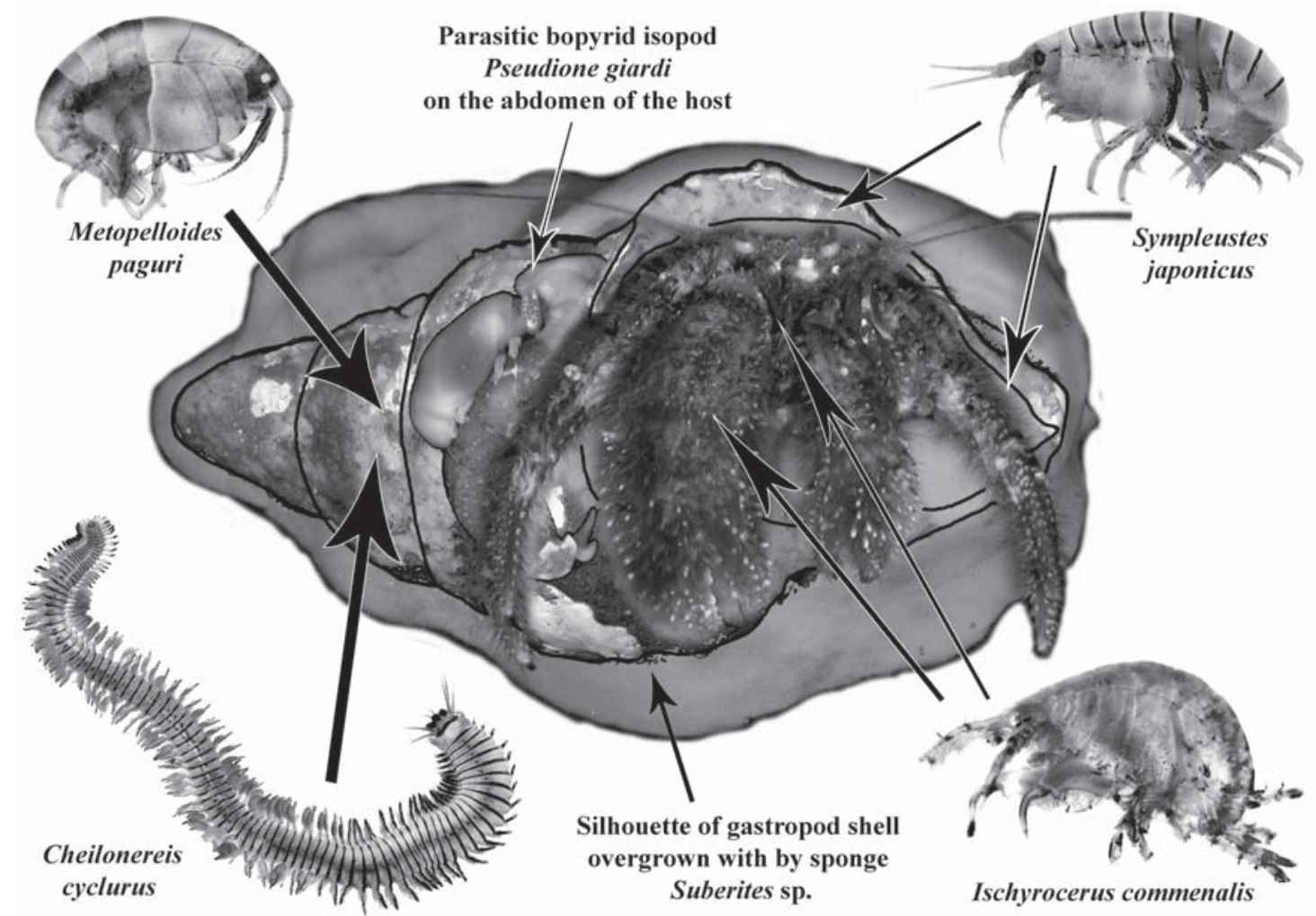

Fig. 2. Schematic representation of the localization of model species of macrosymbionts on the hermit crab (the host) and occupying shell or sponge

Рис. 2. Схематическое изображение локализации модельных видов макро-симбионтов на раке-отшельнике (хозяине) и занимаемой им раковине или губке

from larger predators such as lobsters and octopus by poisonous tentacles of hydractinian polyps [Jensen, 1970; Brooks, Mariscal, 1985a, b; Brooks, Gwaltney, 1993; Buckley, Ebersole, 1994; Weissberger, 1995; Fernandez-Leborans, 2001]. In the Russian fauna one species of deep-water hermit crab Parapagurus benedicti de Saint Laurent, 1972 (=Parapagurus pilosimanus benedicti de Saint Laurent, 1972) inhabiting the depths of $1000-4000 \mathrm{~m}$ is found exclusively living inside cenosarc of hydractinian polyps [Marin, 2013] as at such depth the calcium-based gastropod shell extremely hard to find and they quickly dissolve in sea water.

Apparently, the substrate occupied by hermit crab plays an important role for the associated community of macrosymbionts as each of indicated substrates is inhabited by the certain complex species as well as selected model species of symbionts also have some preferences with the species of host hermit crab (specificity) and the depth of host dwelling (Table 2). For example, the community associated with hermit crab living inside sponges never includes barnacles, polychaete $C$. cyclurus and parasites $P$. giardi that we attribute to the toxicity of sponges for these animals and their larvae as well as the most numerous populations of symbiotic amphipods were found on deeper dwelling hosts.

\section{Localization of symbiotic amphipods}

Among studied species, symbiotic amphipods $S$. japonicas were found in associations with all the collected hosts and depths while other symbiotic amphipod species showed some specificity (Table 1). Specimens of $S$. japonicas were found on outer surface of the shell/sponge and appendages of all species of examined hermit crab without any preferences to the depth of host dwelling [Marin et al, 2013] (Tables 2, 3 ); it was also observed that they can actively swim in the water column, sometimes for significant distances. This may explain their previous records on substrates not associated with hermit crabs such as grass and algae [Gurjanova, 1938]. At the same time, amphipods $M$. paguri and I. commensalis were found dwelling only on such species of hermit crabs as $P$. pectinatus and $P$. parvispinna living in the sponge $S$. domuncula at depths greater than $30 \mathrm{~m}$ (Table 3), and deep water dwelling E. cavimanus found in the museum collections [see Marin, Sinelnikov, 2012].

Our study indicates that there are three different types of host occupation specific for these amphipod species (Fig. 2). Thus, adults and juveniles of I. commensalis prefers to live at the base of the first pereiopod (claws) and feeding appendages of hermit crabs; single immature specimen of this species was found on 
Table 3. The extensiveness of colonization of the host (occurrence) of macro symbionts associated with hermit crabs in the Vostok and Posjeta Bays of the Sea of Japan.

Таблица 3. Экстенсивность колонизации хозяина макросимбионтами, ассоциированными с раки-отшельниками на заливах Восток и Посьета Японского моря.

\begin{tabular}{|l|c|c|c|c|c|}
\hline Host species & M. paguri & S. japonicus & I. commensalis & C. cyclurus & P. giardi \\
\hline $\begin{array}{l}\text { Pagurus ochotensis } \\
\text { (hydractinian cenosarc, depth 5 m) }\end{array}$ & $0 \%$ & $50 \%$ & $0 \%$ & $50 \%$ & $30 \%$ \\
\hline $\begin{array}{l}\text { Pagurus brachiomastus } \\
\text { (gastropod shell, depth 5-30 m) }\end{array}$ & $0 \%$ & $20 \%$ & $0 \%$ & $10 \%$ & $30 \%$ \\
\hline $\begin{array}{l}\text { Pagurus brachiomastus } \\
\text { (sponge Suberites, depth 40-60 m) }\end{array}$ & $100 \%$ & $100 \%$ & $100 \%$ & $0 \%$ & $0 \%$ \\
\hline
\end{tabular}

Table 4. The co-occurrence of macrosymbionts found on hermit crabs in Vostok and Posjeta Bays of the Sea of Japan. Таблица 4. Совместное обитание макросимбионтов на раках-отшельниках в заливах Восток и Посьета Японского моря.

\begin{tabular}{|l|c|c|c|c|c|}
\hline & M. paguri & S. japonicus & I. commensalis & C. cyclurus & P. giardi \\
\hline M. paguri & & + & + & - & - \\
\hline S. japonicus & + & & + & + & + \\
\hline I. commensalis & + & + & & + & - \\
\hline C. cyclurus & - & + & - & - & \\
\hline P. giardi & - & + & - & - & \\
\hline
\end{tabular}

the soft abdomen of the host. Single individuals of $M$. paguri were observed close to the mouth and base of walking appendages of the host while most of specimens of this species (adults and juveniles) were found inside the entire length of the channel of shell/sponge occupied by the host [see Marin, Sinelnikov, 2012]. Amphipods S. japonicus were found on the outer surface of the sponge, the outer edge of the mouth of shell, and walking appendages of hermit crabs; juveniles usually live in the irrigation system and surface osculum of sponges (Fig. 3h, i) [Marin et al., 2013]. For larger host hermit crabs occupying a larger sponge greater number of specimens of $S$. japonicus and I. commensalis were recorded that is also typical for the majority of symbiotic communities [Sokolova, Marin, 2014].

Possible interspecific relationships of model species macrosymbionts

Co-occurrence of macrosymbionts (Table 4) indicates the absence of competition between symbiotic amphipods; their distribution and localization show a clear divergence of ecological niches on the body of the host (Fig. 2). However, co-occurrence of amphipods with other symbionts demonstrate a regular pattern. Thus, the greatest number of amphipods (all species) was found in associations with deeper water sponge dwelling hermit crabs while no parasitic isopods $P$. giardi and large associated polychaetes $C$. cyclurus were found there. In association with shallow water dwelling hermit crabs symbiotic polychaete $C$. cyclurus were never found together with parasitic bopyrid $P$. giardi and infaunal amphipod $M$. paguri while co-occurrence with epifaunal S. japonicus and I. commensalis was noted in rare cases. Based on these data and biology of polychaetes C. cyclurus, which are active predators [Hickok, Davenport, 1957] it is possible to conclude that polychaetes are able to prey on amphipods and parasiting isopods (or their larvae) in the internal cavity of the shell/sponge and possibly on the surface of the shell/sponge (cleaning). Also, amphipods being omnivorous predators abundantly living on their deep dwelling hosts are possibly able to clean their hosts from parasitic isopods too. At the same time, parasitic bopyrid isopods $P$. giardi were most common on shallow hermit crabs which for some reason missing symbiotic polychaetes and amphipods.

ACKNOWLEDGEMENTS. This work has been supported by RFBR (grants \#\# 12-04-0540-a "Diversity of hermit crabs (Decapoda: Anomura: Paguroidea) in the fauna of Russia" (Marin IN), 15-04-05125-a "Symbiotic communities associated with large marine crustaceans: diversity, structure, biological relationship", 15-34-20863_mol_a_ved (Marin I.) and 12-04-31221-mol_a "Symbiotic amphipods of the family Stenothoidae (Crustacea: Malacostraca: Amphipoda) in the fauna of Russia: the diversity and peculiarities of ecology" (Sinelnikov S.). The authors are grateful to the staff of the scientific biological station "Vostok" of A.V. Zhirmunsky Institute of Marine Biology FEB RAS for the help during the field sampling. We are also very thankful to Dr. A.V. Rzhavsky (IEE RAS) for help in identification of spirorbid polychaetes.

\section{References}

Atrashkevich G.I. 2008. [Acanthocephala of common eider (Somateria mollissima L., 1758) in the Sea of Okhotsk] // Materialy IX mezhdunarodnoi nauchnoi konferentsii "Sokhranenie bio- 


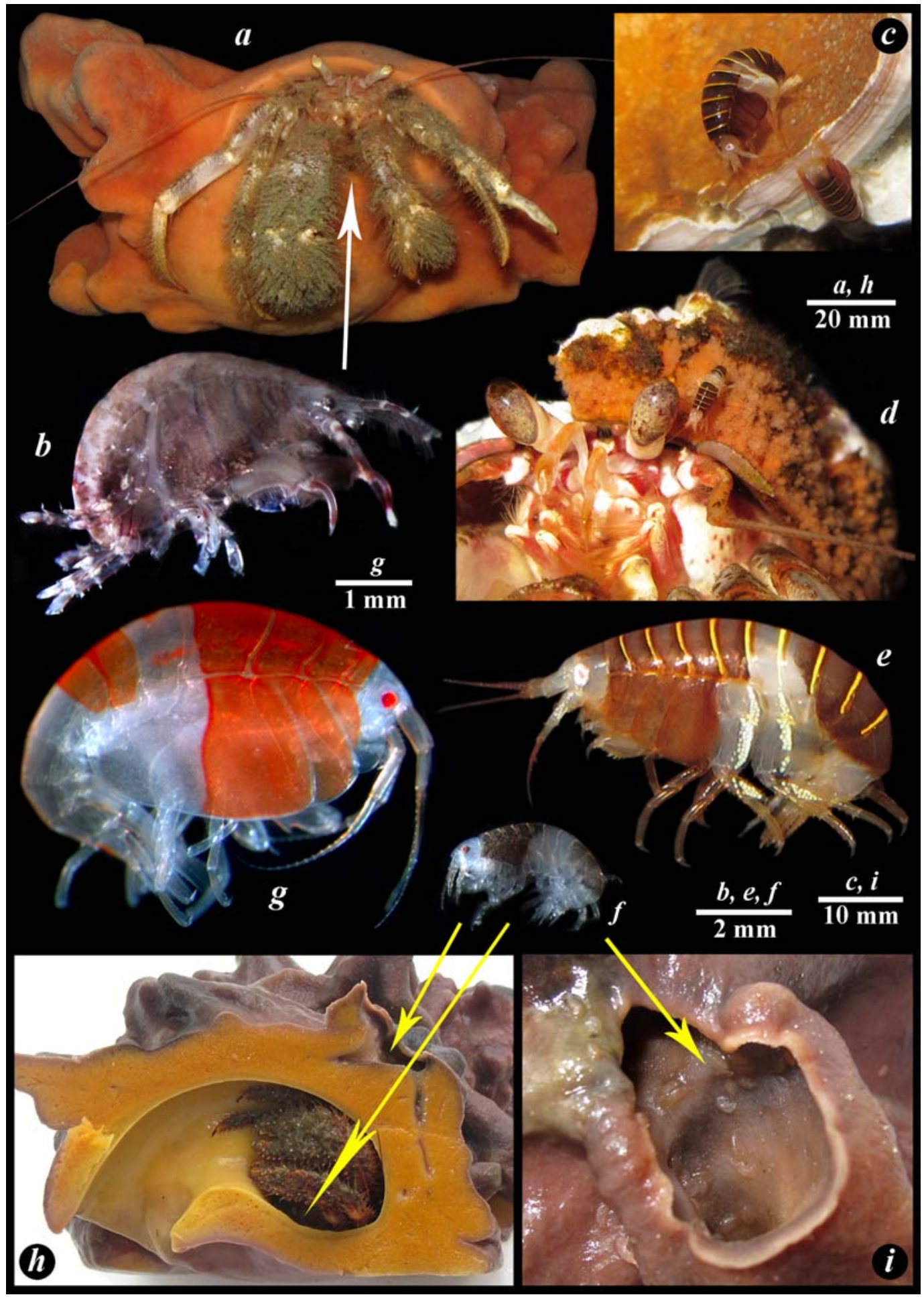

Fig. 3. a - Pagurus parvispina Komai, 1997 in sponge Suberites sp., depth 50-80 m; $b$ - Ischyrocerus commensalis Chevreux, 1900 (white arrow indicates localization on the host); $c, d$ - specimens of Pleusymtes japonica (Gurjanova, 1938) close to the mouth of the shell occupied by hermit crab; $e$ - Pleusymtes japonica; $f$ - juveniles of P. japonica; $g$ - Metopelloides paguri Marin et Sinelnikov, 2012; $h$ - section through the sponge Suberites sp. occupied by hermit crab; $i$ - osculum of sponge Suberites sp (yellow arrow indicates localization of juveniles of $P$. japonica).

Рис. 3. a-Pagurus parvispina Komai, 1997 в губке Suberites sp. 50-80 м; b - Ischyrocerus commensalis Chevreux, 1900 (белая стрелка показывает район встречи особей на раке-хозяине); $c, d$ - особи Pleusymtes japonica (Gurjanova, 1938) на устье раковины, занятой раком-отшельником; e - Pleusymtes japonica; $f$ - молодь P. japonica; $g$ - Metopelloides paguri Marin et Sinelnikov, 2012; $h$ - разрез губки Suberites sp. с раком-отшельником; I - оскулюм губки Suberites sp. (желтые стрелки показывают места находок молоди $P$. japonica). 


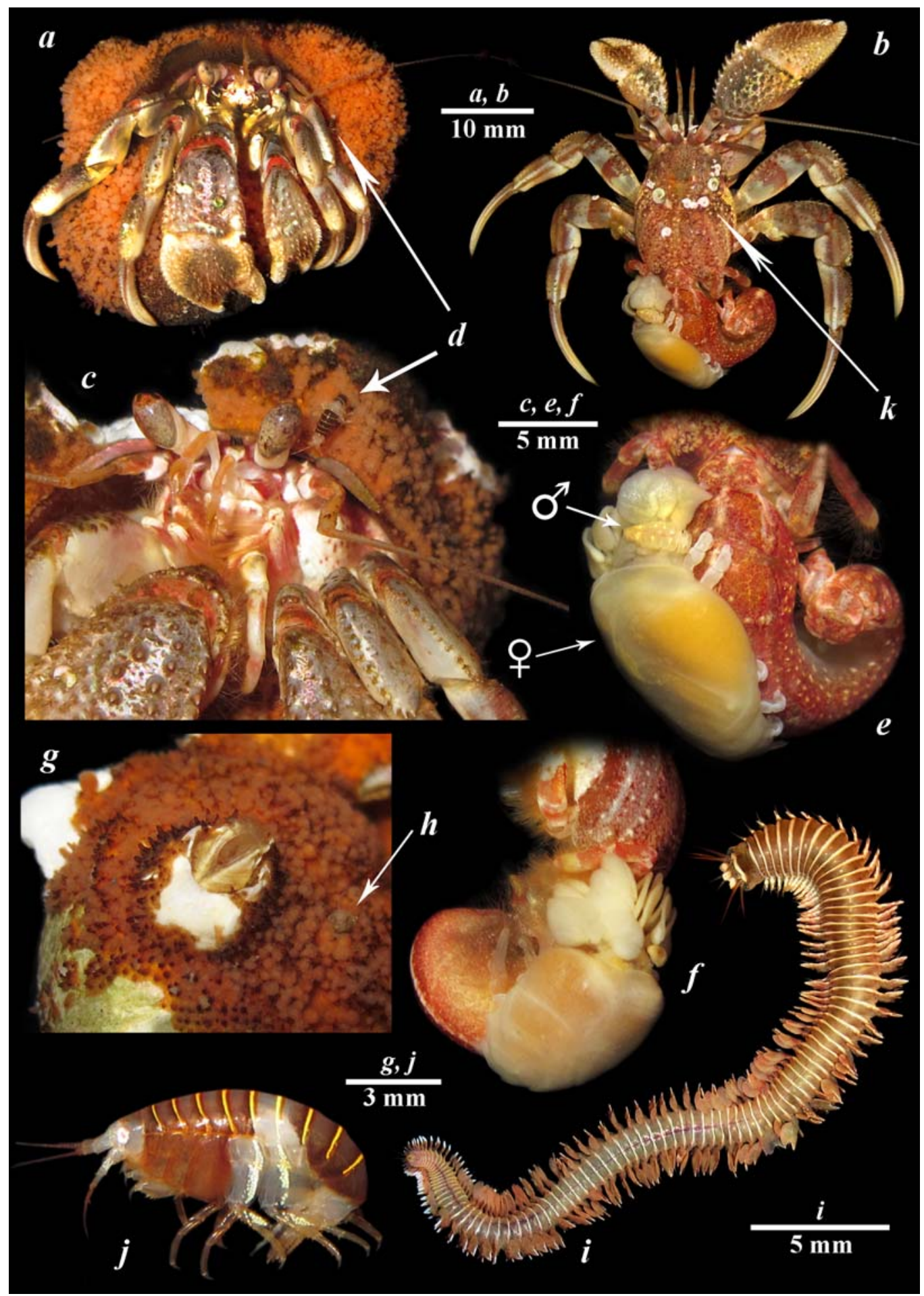

Fig. 4. a - Pagurus ochotensis Brandt, 1851 in the shell overgrown by zooids of Hydractinia, Furuhelma Island, depth 3-5 m; b Pagurus ochotensis Brandt, 1851; c - the same, hermit crab and the mouth of the shell; $\mathrm{d}, \mathrm{j}$ - specimens of Pleusymtes japonica (Gurjanova, 1938); e, f — parasitic bopyrid isopod Pseudione giardi Caiman, 1898 on the abdomen of the host; $\mathrm{g}$ - barnacles Balanus sp. on the shell; $\mathrm{h}$ - polychaetes Dipolydora commensalis (Andrews, 1891); i - polychaete Cheilonereis cyclurus (Harrington, 1897); $\mathrm{k}$ spirorbid polychaetes Bushiella sp. and Circeis armoricana Saint-Joseph, 1894.

Pис. 4. а - Pagurus ochotensis Brandt, 1851 в раковине, обросшей зооидами Hydractinia, о-в Фуругельма, 3-5 м; b - Pagurus ochotensis Brandt, 1851, извлеченный из раковины; с — внешний вид устья раковины и рака-отшельника; $\mathrm{d}$, j — половозрелая особь Pleusymtes japonica (Gurjanova, 1938); e, f — паразитический рак-бопирида Pseudione giardi Caiman, 1898 на абдомене рака-хозяина; g - усоногий рак Balanus sp. на раковине рака-отшельника; $\mathrm{h}$ - полихета Dipolydora commensalis (Andrews, 1891); і - полихета Cheilonereis cyclurus (Harrington, 1897); k — сидячие полихеты-спирорбиды Bushiella sp. и Circeis armoricana SaintJoseph, 1894. 


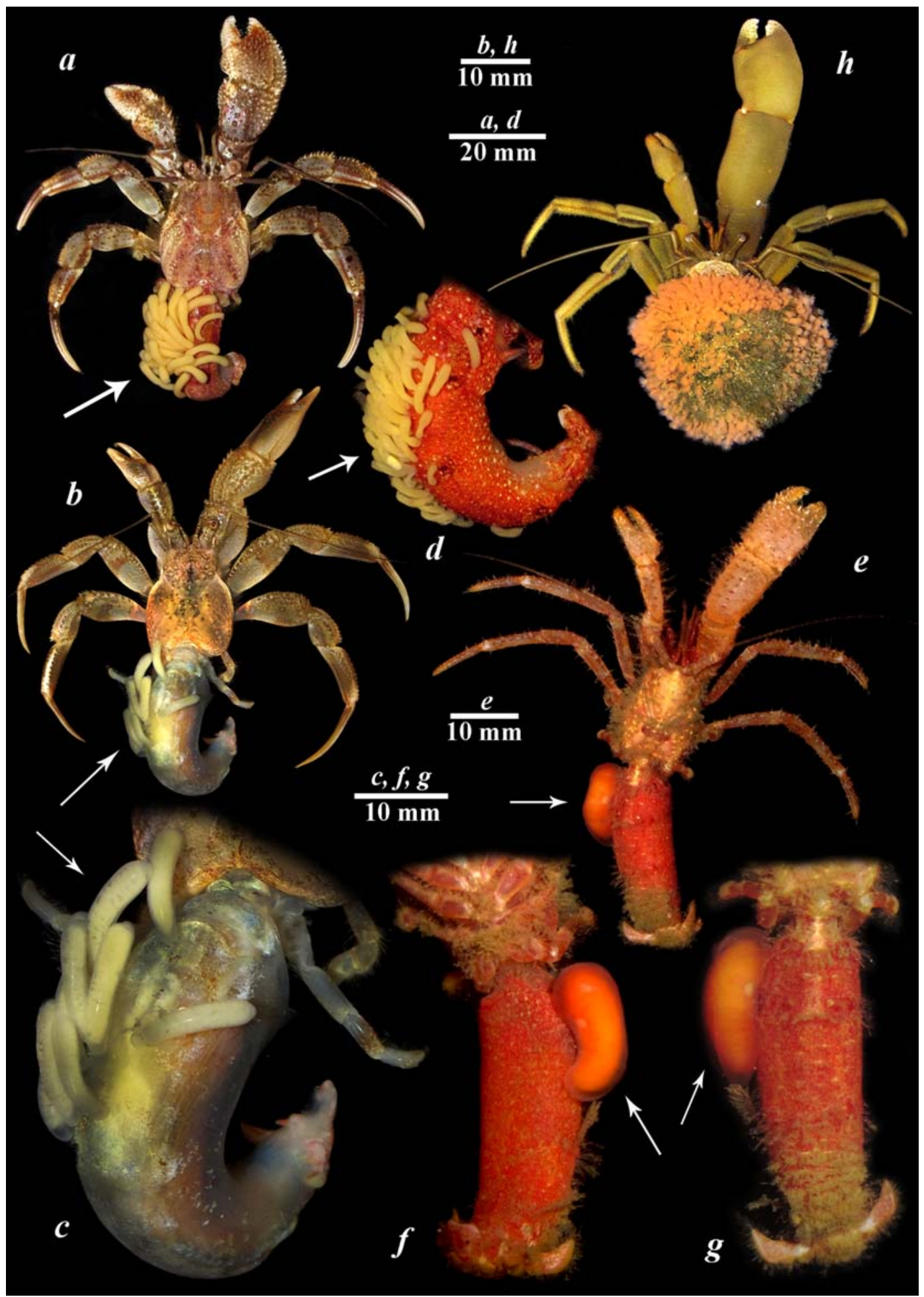

Fig. 5. a - Pagurus ochotensis Brandt, 1851 with parasitic crustaceans Peltogasterella gracilis (Boschma, 1927) on the abdomen; $\mathrm{b}-$ Pagurus gracilipes (Stimpson, 1858) with $P$. gracilis on the abdomen; c - abdomen of $P$. gracilipes with parasites; $\mathrm{d}$ - abdomen of Pagurus brachiomastus (Thallwitz, 1892) with parasitic P. gracilis; e - Discorsopagurus maclaughlinae Komai, 1995 with parasitic crustacean Peltogaster boschmai Reinhard, 1944 on the abdomen; f, g - abdomen of D. maclaughlinae with parasite crustacean; $\mathrm{h}-$ Pagurus middendorffii Brandt, 1851 in the shell overgrown by zooids of Hydractinia, Vityaz Bay, depth 3-5 m.

Рис. 5. а - Pagurus ochotensis Brandt, 1851 с паразитическими ракообразными Peltogasterella gracilis (Boschma, 1927) на абдомене; b - Pagurus gracilipes (Stimpson, 1858) с паразитическими P. gracilis на абдомене; c - абдомен P. gracilipes c паразитами; d - абдомен Pagurus brachiomastus (Thallwitz, 1892) с паразитическими P. gracilis; e - Discorsopagurus maclaughlinae Komai, 1995 с паразитом Peltogaster boschmai Reinhard, 1944 на абдомене; f, g - абдомен D. maclaughlinae с паразитом; h Pagurus middendorffii Brandt, 1851 в раковине, обросшей зооидами Hydractinia, Витязь, 3-5 м. 
raznoobraziya Kamchatki i prilegayushchikh morei" [Proceedings of IX international scientific conference "Conservation of biodiversity of Kamchatka and adjacent seas"] (November 25 26, 2008, Petropavlovsk-Kamchatsky). Petropavlovsk-Kamchatsky: Kamchat-press. P.297-300 [in Russian].

Barnard J.L., Given R.R. 1960. Common pleustid amphipods of southern California, with a projected revision of the family // Pacific Nature. Vol.1. No.17. P.37-48.

Barnard J.L. 1969 The families and genera of marine gammaridean Amphipod // United States National Museum Bulletin. Vol.271. P.1-535.

Barnard J.L., Karaman G.S. 1991. The families and genera of marine gammaridean Amphipoda (except marine gammaroids) // Records of the Australian Museum. Supplement 13. P.1866 .

Bousfield E.L., Hendrycks E.A. 1995. The amphipod family Pleustidae on the Pacific coast of North America. Part III. Subfamilies Parapleustinae, Dactylopleustinae, and Pleusirinae: systematics and distributional ecology // Amphipacifica. Vol.2. P.65-133.

Brooks W.R., Gwaltney C.L. 1993. Protection of symbiotic cnidarians by their hermit crab hosts: evidence for mutualism // Symbiosis. Vol.15. P.1-13.

Brooks W.R., Mariscal R.N. 1985à. Shell entry and shell selection of hydroid-colonized shells by three species of hermit crabs from the northern Gulf of Mexico // Biological Bulletin of Marine Biology. Vol.168. P.1-17.

Brooks W.R., Mariscal R.N. 1985b. Protection of the hermit crab Pagurus pollicaris Say from predators by hydroid-colonized shells // Journal of Experimental Marine Biology and Ecology. Vol.87. P.111-118.

Buckley W.J., Ebersole J.P. 1994. Symbiotic organisms increase the vulnerability of a hermit crab to predation // Journal of Experimental Marine Biology and Ecology. Vol.182. P.49-64.

Check-list of species of free-living invertebrates of the Russian Far Eastern Seas. 2013 // Explorations of the fauna of seas. St. Petersburg: ZIN RAS. Vol.75. No.83. P.1-256.

Cuadras J., Pereira F. 1977. Invertebrates associated with Dardanus arrosor (Anomura, Diogenidae) // Vie Milieu. Vol.27. P.301-310.

Dvoretsky A.G., Britayev T.A. 2009. Population biology of symbiotic amphipods Ischyrocerus spp. and their relationships with the host, the red king crab, in the Barents Sea // Invertebrate Zoology. Vol.6. No.2. P.91-103.

Dvoretsky A.G., Dvoretsky V.G. 2012. New data on the symbiosis of Ischyrocerus amphipods colonizing the eggs of the host species, red king crab // Doklady Biological Sciences. Vol.445. No.1. P.255-257.

Dvoretskiy A.G., Dvoretskiy V.G. 2013. [Fouling community of the Red King crab in Dalnezelenetskaya Bay (Eastern Murman, Barents Sea): comparative analysis of seasonal trends] // Trudy Karelskogo Nauchnogo Tsentra RAN. Vol.2. P.78-85 [in Russian].

Dualan I.V., Williams J.D. 2011. Palp growth, regeneration, and longevity of the obligate hermit crab symbiont Dipolydora commensalis (Annelida: Spionidae) // Invertebrate Biology. Vol. 30. P. 64-276.

Fernandez-Leborans G. 2001. A review of the species of protozoan epibionts on crustaceans. III Chonotrich ciliates // Crustaceana. Vol. 74. P. 581-607

Gasca R., Haddock H.D. 2004. Associations between gelatinous zooplankton and hyperiid amphipods // Hydrobiologia. Vol.530/ 531. P.529-535.

Glynn P.W. 1983a. Crustacean symbionts and defense of corals // Coevolution. Chicago: Univ. Press. P.111-178.

Glynn P.W. 1983b. Increased survivorship in corals harboring crustacean symbionts // Marine Biology Letters. Vol.4. P.105-111.

Glynn P.W. 1987. Some ecological consequences of coral-crustacean guard mutualisms in the Indian and Pacific Oceans // Symbiosis. Vol.4. P.301-324.

Glynn P.W., Krupp D.A. 1986. Feeding biology of a Hawaiian sea star corallivore, Culcita novaeguineae Muller \& Troschel // J. Exp. Mar. Biol. Ecol. Vol.96. P.75-96.
Gurjanova E.F. 1951. [Amphipods of the seas of the USSR and surrounding waters (Amphipoda-Gammaridea)] // Opredeliteli po faune SSSR. Leningrad: AN SSSR Publ. Vol.41. P.1-1029 [in Russian].

Jensen K. 1970. The interaction between Pagurus bernhardus (L.) and Hydractinia echinata (Fleming) // Ophelia. Vol.8. P.135-144.

Hickok J.H., Davenport D. 1957. Further studies on behavior of commensal polychaetes // Biological Bulletin. Vol.113. No.3. P.397-406.

Isaeva V.V., Sukalyuk A.I. 2007. [Colonial Rhizocephalans (Crustacea, Rhizocephala): Asexual Reproduction, Stem Cells, and Reproductive Strategy]. Moscow: Nauka. 120 pp. [in Russian]

Khokhlova I.G. 1986. [Acanthocephala of terrestrial vertebrate fauna of the USSR]. Moscow: Nauka. 277 pp. [in Russian].

Marin I.N. 2013. [Small Atlas of Decapod Crustaceans of Russia]. Moscow: KMK Scientific Press. 145 pp. [in Russian]

Marin I.N., Korn O.M., Kornienko E.S. 2011. Symbiotic crab Sestrostoma balssi (Shen, 1932) (Varunidae: Gaeticinae) from Vostok Bay, Sea of Japan: a new species for the fauna of Russia // Russian Journal of Marine Biology. Vol.37. No.6. P.509-510

Marin I.N., Korn O.M., Kornienko E.S. 2012. Hermit Crabs Pagurus parvispina Komai, 1997 and Discorsopagurus maclaughlinae Komai, 1995 (Decapoda: Paguridae): New Records for Russian Waters of the Sea of Japan // Russian Journal of Marine Biology. Vol.38. No.3. P.275-278.

Marin I.N., Kornienko E.S. 2014. The list of Decapoda species from Vostok Bay Sea of Japan // Biodiversity and Environment of Far East Reserves. Vol.2. P.50-72.

Marin I., Sinelnikov S. 2012. Metopelloides paguri sp. nov., a new species of symbiotic stenothoid amphipod (Crustacea: Amphipoda: Stenothoidae) associated with sublittoral hermit crabs from the Russian coasts of the Sea of Japan // Zootaxa. Vol.3244. P.59-67.

Marin I., Sinelnikov S., Sokolova A. 2013. Ecological remarks and re-description of the hermit crab-associated pleustid amphipod Pleusymtes japonica (Gurjanova, 1938) (Crustacea: Amphipoda: Pleustidae: Pleusymtinae) from the Sea of Japan // Zootaxa. Vol.3640. No.4. P.581-588.

Markham J.C. 2010. A worldwide list of hermit crabs and their relatives (Anomura: Paguroidea) reported as hosts of Isopoda Bopyridae // Memoirs of Museum Victoria. Vol.60. No.1. P.7177.

McDermott J.J. 2001. Symbionts of the hermit crab Pagurus longicarpus Say, 1817 Decapoda: Anomura: New observations from New Jersey waters and a review of all known relationships // Proceedings of the Biological Society of Washington. Vol.114. No.3. P.624-639.

McDermott J.J., Williams J.D., Boyko C.B. 2010. The unwanted guests of hermits: A global review of the diversity and natural history of hermit crab parasites // Journal of Experimental Marine Biology and Ecology. Vol.394. P.2-44.

Reiss H., Knäuper S., Kröncke I. 2003. Invertebrate associations with gastropod shells inhabited by Pagurus bernhardus (Paguridae) - secondary hard substrate increasing biodiversity in North Sea soft-bottom communities // Sarsia. Vol.88. P.404415.

Sokolova A.M., Marin I.N. 2014. [The relationship between biodiversity of symbiotic community and host's size in the case of the sponge Haliclona fascigera (Demospongiae: Haplosclerida) and its inhabitants] // Povolzhskiy Ekologicheskiy Zhurnal. No.4. P.508-515 [in Russian].

Stimpson J. 1990. Stimulation of fat-body production in the polyps of the coral Pociilopora darmicornis by the presence of mutualistic crabs of the genus Trapezia // Marine Biology. Vol.106. P.211-218

Tandberg A.H.S., Vader W. 2009. A redescription of Metopa species (Amphipoda, Stenothoidae) based on the type material. 1. Zoological Museum, Copenhagen (ZMUC) // Zootaxa. Vol.2093. P.1-36. 
Tandberg A.H.S., Vader W., Berge J. 2010. Studies on the association of Metopa glacialis (Amphipoda, Crustacea) and $\mathrm{Muscu}$ lus discors (Mollusca, Mytilidae) // Polar Biology. Vol.33. No.10. P.1407-1418.

Taylor P.R. 1979. An association between an amphipod, Liljebor gia sp., and the hermit crab, Pagurus hemphilli (Benedict) // Mar. Behav. Physiol. Vol.6. P.185-188.

Weissberger E.J. 1995. Association of the hermit crab Pagurus longicarpus Say 1817, with symbiotic hydroids: Consequences of predation by lobsters // Crustaceana. Vol.68. P.739-750.

Williams J.D. 1995. Feeding biology of Polydora commensalis (Polychaeta:Spionidae). Unpublished Honors Thesis. Department of Biology, Franklin and Marshall College, Lancaster, Pennsylvania. 34 pp.
Williams J.D., McDermott J.J. 1997. The feeding behavior of Diploydora commensalis (Polychaeta: Spionidae): particle capture, transport and selection // Invertebrate Biology. Vol.116. P.115-123.

Williams J.D., McDermott J.J. 2004. Hermit crab biocoenoses: a worldwide review of the diversity and natural history of hermit crab associates // Journal of Experimental Marine Biology and Ecology. Vol.305. No.1. P.1-128.

Vader W. 1972. Associations between amphipods and mollusks. A review of published records // Sarsia. Vol.48. P.13-18.

Vader W. 1984. Associations between amphipods (Crustacea: Amphipoda) and sea anemones (Anthozoa: Actiniaria) // Australian Museum Memoir. Vol.18. No.13. P.141-153.

Responsible editor V.A. Spiridonov 